\title{
Management of Human Resources in the Aspect of Innovativeness
}

\author{
Marcin Waldemar Staniewski ${ }^{1}$
}

ABSTRACT The importance of human capital is widely emphasised in the literature as regards the achievement of durable competitive edge. It turns out that a company may achieve an equally durable competitive edge owing to its innovativeness. Which source should be chosen by a company's managers, which source should they focus their attention and resources on so as not to be driven out of the market - and even more so - to achieve great success on it? This article provides an unambiguous answer to this question. Both these sources are inseparable and must be used simultaneously. The article presents dependencies occurring between Human Resource Management and innovativeness identifying the critical personnel areas from the viewpoint of innovativeness and simultaneously verifying the usefulness of various models of Human Resource Management.

Key words: innovativeness, human resources, competitive advantage

JEL Classification: M50

${ }^{1}$ Faculty of Management and Finance, University of Finance and Management in Warsaw, Poland

\section{Introduction}

The area of human resource management is one of the basic elements of an effectively managed company. In the era of the knowledge-based economy, its importance becomes strategic as the effectiveness of activity within this scope largely determines the achievement of the company's competitive advantage. Knowledgebased resources can be particularly important to ensure this advantage (McEvily \& Chakravarthy, 2002: 285-305), but they may also play a significant role in the process of creating innovativeness (Galunic \& Rodan, 1998: 1193-1201), as well as to contribute to the improvement of the organisational performance (Wiklund \& Shepherd, 2003: 1307-1314).

It happens so because the area referred to above pertains to the management of an organisation's most valuable capital, i.e. the human capital and the knowledge it possesses. However, innovativeness is also needed,

Corespondence concerning to this article should be addressed to: staniewski@vizja.pl and perhaps primarily, as regards the management of these valuable resources. Owing to such an approach, improved effects can be expected.

\section{Human Resource Management system in an innovative organisation}

The most appropriate HRM practices for organisations attempting to gain a competitive advantage based on innovation will include different practices compared to those appropriate for companies searching for other sources of their competitive advantage (Jimenez-Jimenez \& Sanz-Valle, 2005: 366).

However, it is difficult to find an agreement between researchers as regards innovation-supporting HRM practices in the literature on the subject (theoretical and empirical studies).

Some theoretical studies focus on several isolated HRM practices while other studies focus on the HRM system used by individual organisations.

The majority of the aforementioned theoretical studies were based on the models devised by R.E. 
Miles \& C.C. Snow (1984) as well as R.S. Schuler \& S.E. Jackson (1987).

The former model proposed the development of a market-oriented HRM system, i.e. companies were defined as "searchers" and characterised by a constant search for new products and markets, owing to which they become innovative. The authors of the model claim that it is difficult to ensure appropriate skills from within the organisation for serving new markets or devising a new product, all the more so because skills are needed quickly. Therefore, the authors suggest searching for these skills outside the organisation, every time the organisation needs them, e.g. the development of a market-oriented HRM system. HRM practices included in the aforementioned HRM system are similar to those proposed by L.R. Gómez-Mejia et al. (2004) - (cf. Table 1).
The other model is a combination of HRM practices and three types of strategy: costs, quality and innovation defined by M.E. Porter (1980) (competitiveness strategies). This model consists of analysing employee behaviour in respect of requirements imposed by the individual competitiveness strategies, and next, of the development of appropriate behaviour using HRM practices. Considering the introduction of an innovation strategy, an organisation must develop flexibility and uncertainty and ambiguity tolerance in its employees (i.e. to educate people who are capable of taking risks and assume responsibility, talented, able to work in cooperation and interdependence in the achievement of long-term objectives). The HRM practices they propose remind the approach of R.W. Beatty \& C.E. Schneier (1997), C. Mabey \& G. Salaman (1995) and M.A. Sheppeck \& J. Militello (2000) - (cf. Table 1).

Table 1. HRM practices supporting an organisation's innovativeness

\begin{tabular}{|c|c|c|}
\hline HRM practices & R.E. Miles \& C.C. Snow Model & R.S. Schuler \& S.E. Jackson Model \\
\hline Recruitment and selection & $\begin{array}{l}\text { "Buying"knowledge and skills } \\
\text { Employment almost exclusively from the outside of the organization } \\
\text { Selection may use psychological tests; } \\
\text { Ensuring very low employment security } \\
\text { Rare (if any) integration activity targeted at employees. }\end{array}$ & $\begin{array}{l}\text { Use of external recruitment sources; } \\
\text { Looking for technical and research competences; } \\
\text { High employment security. }\end{array}$ \\
\hline Training & $\begin{array}{l}\text { Identification and outsourcing of skills: } \\
\text { Limited training programmes. }\end{array}$ & $\begin{array}{l}\text { Broad application; } \\
\text { Impose responsibility on the personnel for self-education; } \\
\text { Ensuring work making it possible for employees to develop skills, } \\
\text { which they will be able to use in other positions in the organisation; }\end{array}$ \\
\hline $\begin{array}{l}\text { Development and internal } \\
\text { possibilities of career } \\
\text { development }\end{array}$ & Little use of internal career ladder. & $\begin{array}{l}\text { Broad use of career paths; } \\
\text { Obligatory development of competences }\end{array}$ \\
\hline Employee assessment & $\begin{array}{l}\text { Effect-oriented assessment; } \\
\text { Identification of personnel needs; } \\
\text { Department/corporate employee assessment; } \\
\text { Comprehensive comparison. }\end{array}$ & $\begin{array}{l}\text { Use of the following criteria: assessment of the work performance } \\
\text { process and its effects; } \\
\text { Use of employee assessment oriented for long-term team achievements. }\end{array}$ \\
\hline Remuneration & $\begin{array}{l}\text { Result-oriented; } \\
\text { Externally competitive; } \\
\text { Total remuneration of strongly competitive nature. }\end{array}$ & $\begin{array}{l}\text { Application of a broad range of rewards; } \\
\text { Internally justified system (fair); } \\
\text { Low basic rate, increased by transferring to employees shares in the } \\
\text { company equity and a rich cafeteria package; } \\
\text { Rewards for innovative teams; } \\
\text { Competence-based remuneration. }\end{array}$ \\
\hline Other HRM practices & $\begin{array}{l}\text { Low employee participation; } \\
\text { Frequent work analysis; } \\
\text { Work enrichment. }\end{array}$ & $\begin{array}{l}\text { High employee participation; } \\
\text { Frequent work analysis; } \\
\text { Work enrichment; } \\
\text { Inter-department teams; } \\
\text { Communication: feedback on the sales of new products. }\end{array}$ \\
\hline
\end{tabular}


Other authors also studied relations occurring between innovation and HMR practices.

As regards the process of recruitment and selection, there is agreement on the importance of using external sources of recruitment in order to comply with the innovation strategy (Gómez-Mejia et al., 2004; Miles \& Snow, 1984; Olian \& Rynes, 1984; Schuler \& Jackson, 1987, Sonnenfield \& Peiperl, 1988). It needs to be added that L.K. Stroh \& A.H. Reilly (1994) did not find a relationship between the strategy and recruitment in their empirical research; however, other research results (Raghuram \& Arvey, 1994) confirm the usefulness of external recruitment sources as regards an organisation's innovativeness

There is no agreement between researchers as regards the degree of employment security, which should be ensured to an organisation's employees. Other authors (Miles \& Snow, 1984; Olian \& Rynes, 1984; Sheppeck \& Militello, 2000; Sonnenfeld \& Peiperl, 1988) argue that innovative organisations should have a clearly defined employment strategy (flexible employment structure) to ensure free access to specific skills and knowledge which will be required by the market at a given time. However, other researchers defend employment security as a means of gaining employee involvement in the organisation's matters, which favours its innovativeness (Schuler \& Jackson, 1987). These dependencies are also corroborated by other researchers. S.E. Jackson et al. (1989) have found dependence between innovativeness and employment security, and J. Storey et al. (2002) observed that organisations do not use temporary employment contracts for employees employed in the "innovation department".

Considering the aspect of employee training, some theoretical studies imply broad application of training to develop the personnel's skills and knowledge needed for innovativeness (Beatty \& Schneier, 1997; Cascio, 1990; Mabey \& Salaman, 1995; Schuler \& Jackson, 1987). Others, on the contrary, recommend that organisations should outsource their skills and knowledge - which is why they propose a narrow use of training.

The results of empirical studies are not clear and unambiguous either. Some of them have found evidence of a positive relationship between the number of training sessions provided to an organisation's employees and its innovativeness (Ding \& Akhtar, 2001; Jack- son et al., 1989; Johnson et al., 1996; Mark \& Akhtar, 2003). For contrast, the research by S. Raghuram \& R.D. Arvey (1994) should be quoted as it indicates the reverse relationship.

Career paths are an equally conflict-generating issue. Some authors propose a narrow use of career paths (Kydd \& Oppenheim, 1990; Laursen \& Foss, 2003; Mark \& Akhtar, 2003; Miles \& Snow, 1984; Sonnenfeld \& Peiperl, 1988), while others recommend their broad application as, in their opinion, career paths support an organisation's innovativeness (Petroni, 1999).

As regards employee assessment, both theoretical studies (Gupta \& Singhal, 1993; Mabey \& Salaman, 1995; Mumford, 2000) and empirical ones (Jackson et al., 1989; Mark \& Akhtar, 2003) recommend that it should be used. The only question, that is not obvious, is whether the assessment should be results-oriented (Beatty \& Schneier, 1997; Miles \& Snow, 1984) or oriented on the work performance process (Kydd \& Oppenheim, 1990; Mumford, 2000) or on both (Mabey \& Salaman, 1995; Schuler \& Jackson, 1987).

As regards the best remuneration system from the viewpoint of an organisation's innovativeness, the literature suggests the application of rewards (Gómez-Mejia et al., 2004; Miles \& Snow, 1984; Schuler \& Jackson, 1987) and the application of an integrated remuneration system (Gómez-Mejia \& Welbourne, 1988). The results of empirical research confirm these recommendations (Laursen, 2002; Laursen \& Foss, 2003).

The literature proposes a range of other HRM practices supporting an organisation's innovativeness, e.g. job enrichment (Schuler \& Jackson, 1987), teamwork (Eisenhardt \& Tabrizi, 1995; Laursen, 2002), external and internal communication (Damanpour, 1991) and employee participation (involvement) (Jimenez-Jimenez \& Sanz-Valle, 2005). However, there is no agreement about the last issue. Some researchers point out that innovativeness requires a high degree of employee involvement and participation (Damanpour, 1991; Hurley \& Hult, 1998; Mark \& Akhart, 2003; Schuler \& Jackson, 1987), while others attach less importance to it, in accordance with their model of "acquiring human capital" as opposed to "building human capital" (Miles \& Snow, 1984; Snell \& Lepak, 1999).

Some studies do not focus on isolated HRM practices, but on the HRM system. R.E. Miles \& C.C. Snow (1984) have proposed a market-oriented system, while 

well-paid employees deriving satisfaction from challenges brought by their tasks and responsibilities. An individualised reward is characterised by more autonomy, promotion, higher remuneration, appreciation and work full of challenges.

Employee remuneration is another element, which is significant from the point of view of HRM innovativeness. Employees must be aware that their individual contribution is rewarded, taking into account their individual performance. The contribution must always be equal to results - i.e. if an employee is highly qualified and experienced, they will eventually receive higher remuneration and their tasks will be characterised by a higher level of responsibility than in the case of an employee, whose qualifications are not high and whose experience is not so rich.

Work organisation based on task-oriented teams is another area of HRM innovativeness. Task- or projectoriented teams are formed to achieve greater objectives compared to the objectives, which could be achieved by each employee working on their own. Therefore, building effective teams is important for the success of the organisation and especially for service organisations. The best managers are those, who can form a real team out of a group of individuals. Managers of HRM units must master the skill of understanding and recognising unique talents, knowledge and creativity of team members. Besides, they need to be able to build trust between team members, a work climate under trust conditions favouring open expression of ideas, opinions, objections, emotions and asking questions (Jinzhao, 2007: 61).

As regards HRM innovativeness, the delegation of authority rights becomes important. Delegation of authorisation rights is a process of assigning responsibility and power to an employee in order to fulfil tasks. This kind of practice may develop employees' skills and, as it is a sign of trust, it may lead to better interpersonal relationships and work performance. To be true managers of success, managers of HRM units must employ able people and then help them become even better. On the other hand, employees, who appreciate such an approach and activity of the management, will be more loyal, efficient and effective.

The belief and conviction of numerous managers that only they are able to do the job well, i.e. faster and better than their subordinates, is probably the greatest barrier for the delegation of authorisation rights. The main objective of work delegation should include the development of personnel skills and talent. Managers, who delegate authorisation rights in an effective manner, at the same time share their knowledge with the employees, ensure training and coaching necessary to achieve success by employees (Jinzhao, 2007: 62).

\section{Conclusions}

Summing up the literature review, it can be concluded that there is an agreement among researchers on the relationship between HRM and an organisation's innovativeness and on the application of individual practices favouring innovativeness, i.e. the use of external recruitment sources, employee assessment and rewarding. However, there is no agreement in the literature as far as other HRM practices are concerned, i.e. employment security, training, career paths and employee participation. It should be noted that empirical studies present diverse results in this area.

According to D. Jimenez-Jimenez \& R. Sanz-Valle (2005: 373), an organisation implementing an innovation strategy will be characterised by the application of a system encompassing employee assessment, motivating remuneration, creating possibilities of an internal career and will be striving to achieve high employee participation. These authors emphasize that HRM is a key element in the achievement of success as regards an organisation's innovativeness (Jimenez-Jimenez \& Sanz-Valle, 2005: 375).

Moreover, on the basis of research conducted by D. Jimenez-Jimenez \& R. Sanz-Valle (2005), it can be concluded that R.S. Schuler \& S.E. Jackson's model accounts more for the dependencies occurring between HRM and an organisation's innovativeness than the model devised by R.E. Miles and C.C. Snow. These results considerably contribute to explaining doubts arising from the literature on the subject. They show that organisations using innovation strategies are more willing to use the internal job market rather than the external one (as implied by R.S. Schuler \& S.E. Jackson). Therefore, it seems that the application of HRM practices is oriented in this case on the formation of stable employee groups in a company, which is capable of taking risks and not afraid of experimenting and which can assume responsibility for decisions concerning their work. Such a work environment is more 
favourable for the creation of conditions for the emergence of new ideas, which constitute the beginning of all kinds of innovation.

\section{References}

1. Agarwala T., Innovative human resource practices and organisational commitment: an empirical investigation, "International Journal of Human Resources Management” March 2003, 14:2, pp. 175-197.

2. Akgun A.E., Keskin H., Byrne J.C., Aren S., Emotional and learning capability and their impact on product innovativeness and firm performance, “Technovation” 2007, 27, pp. 501-513.

3. Barney J.B., Looking inside for competitive advantage, [w:] Strategic human resource management, red. R. S. Schuler, S. E. Jackson, Blackwell Publishing, Oxford, 1999, pp. 131.

4. Beatty R.W., Schneier C.E., New HR roles to impact organisational performance: from 'partners' to 'players', "Human Resource Management” 1997, vol. 36, no. 1, pp. 29-37.

5. Brown D., Good ideas going wrong. Far from being faddish, innovative HR can add value to an organisation - when done right, "Canadian HR Reporter” May 2002, 15, 9, p. 2.

6. Brown D., Innovative HR ineffective in manufacturing firms, "Canadian HR Reporter” April 2003, 16,7, p. $1 \& 10$.

7. Camelo-Ordaz C., Fernandez-Alles M.L., ValleCabrera R., Top management team's vision and Human Resources Management practices in innovative Spanish companies, "International Journal of Human Resource Management", April 2008, vol. 19, no. 4, pp. 620-638.

8. Cascio W.F., Strategic human resource management in high technology industry, [w:] Organisational Issues in High Technology Management, red. L.R. Gómez-Mejia, M.W. Lawless, JAI Press, Greenwich 1990.

9. Damanpour F., Organisational innovation: a meta-analysis of effects of determinants and moderators, "Academy of Management Journal" 1991, vol. 34, no. 3, pp. 550-590.

10. Ding D.Z., Akhtar S., The organisational choice of human resource management practices: A study of Chinese enterprises in three cities in the PRC,
"International Journal of Human Resource Management” 2001, vol. 12, no. 6, pp. 946-964.

11. Eisenhardt K.M., Tabrizi B.N., Accelerating adaptive processes: product innovation in the global computer industry, "Administrative Science Quarterly" 1995, vol. 40, pp. 84-110.

12. Gabriel M., Robitaille P., How HR can support innovation, "Canadian HR Reporter" May 2007, 20, 9, p. 23.

13. Galbraith J.R., Human resource policies for the innovating organisation, [w:] Strategic Human Resources Management, red. C. Fombrun, N.M. Tichy, M.A. Davenna, John Wiley and Sons, New York, 1984.

14. Galunic C., Rodan S., Resource recombinations in the firm: Knowledge structures and the potential for Schumpeterian innovation, "Strategic Management Journal" 1998, 19(12), pp. 1193-1201.

15. Gómez-Mejia L.R., Balkin D.B., Cardy R.L., Managing Human Resources, Prentice Hall, Upper Saddle River, New York, 2004.

16. Gómez-Mejia L.R., Welbourne T.M., Compensation strategy: an overview and future steeps, "Human Resource Planning” 1988, vol. 11, no. 3, pp. 173-189.

17. Gupta A.K., Singhal A., Managing human resources for innovation and creativity, "Research Technology Management” 1993, vol. 36, pp. 41-48.

18. Hribe F., No risk, no innovation: Does innovation happen because of HR systems or in spite of them?, "Canadian HR Report" December 2003, 1, vol. 16, issue 21, p. 26.

19. Hurley R.E., Hult G.T.M., Innovation, market orientation and organisational learning: an integration and empirical examination, "Journal of Marketing" July 1998, vol. 62, pp. 42-54.

20. Jackson S.E., Schuler R.S., Rivero J.C., Organisational characteristics as predictors of personnel practices, "Personnel Psychology" 1989, vol. 42, pp. 727-786.

21. Jimenez-Jimenez D., Sanz-Valle R., Innovation and human resource management fit: an empirical study, "International Journal of Manpower" 2005, 26, 4, pp. 364-397.

22. Jinzhao W., Innovations of Human Resources Management in lodging industry, "Canadian Social Science" December 2007, vo. 3, no. 6, pp. 58-63. 
23. Johnson J., Baldwin J.R., Diverty B., The implications of innovation for human resource strategies, "Future" 1996, vol. 28, no. 2, pp. 103-19.

24. Kydd C.T., Oppenheim L., Using human resource management to enhance competitiveness: Lessons from four excellent companies, "Human Resource Management" 1990, vol. 29, no. 2, pp. 145-166.

25. Laursen K., Foss N.J., New human resource management practices, complementarities and the impact on innovation performance, "Cambridge Journal of Economics" 2003, vol. 27, pp. 243-263.

26. Laursen K., HRM practices for innovation performance, "International Journal of the Economic Business" 2002, 9(1), pp. 139-166.

27. Laursen K., The importance of sectoral differences in the application of complementary HRM practices for innovation performance, "International Journal of the Economics of Business" 2002, vol. 9, no. 1, pp. 139-156.

28. Lepak D.P., Snell S.A., The human resource architecture: Toward a theory of human capital allocation and development, "Academy of Management Review" 1999, 24(1), pp. 31-48.

29. Lopez-Cabrales A., Perez-Luno A., Valle Cabrera R., Knowledge as mediator between HRM practices and innovative activity, "Human Resource Management” 2009, Vol. 48, No. 4, pp. 485-503.

30. Mabey C., Salaman G., Strategic Human Resource Management, Blackwell, London 1995.

31. Mark S.K.M., Akhtar S., Human resources management practices, strategic orientations, and company performance: a correlation study of publicly listed companies, "Journal of American Academy of Business" 2003, vol. 2, no. 2, pp. 510515.

32. Mavondo F.T., Chimhazni J., Stewart J., Learning orientation and market orientation: Relationship with innovation, human resource practices and performance, "European Journal of Marketing" 2005, 39, 11/12, pp. 1235-1392.

33. McEvily S.K., Chakravarthy B., The persistence of knowledge-based advantage: an empirical test for product performance and technological knowledge, "Strategic Management Journal” 2002, 23(4), pp. 285-305.

34. Michie J., Sheehan M., HRM practices, R \& D expenditure and innovative investment: evidence from the UK's 1990 workplace industrial relations survey (WIRS), "Industrial and Corporate Change” 1999, vol. 8, no. 2, pp. 211-234.

35. Miles R.E. , Snow C.C., Designing strategic human resources systems, "Organisational Dynamics" Summer 1984, pp. 36-52.

36. Millicent N., Brice J., Jr., Emotional and informational social support: exploring contrasting influence of human resource management innovation, "Journal of Organisational Culture, Communications and Conflicts" 2008, Volume 12, No. 1, pp. 71-82.

37. Morrisette R., Alternative Work Practices and Quit Rates: Methodological Issues and Empirical Evidence for Canada, Analytical Studies Branch in its series Analytical Studies Branch Research Paper Series, Statistics Canada, Canada 2003.

38. Mumford M.D., Managing creative people: strategies and tactics for innovation, "Human Resource Management Review” 2000, vol. 10, no. 3, s. 315351.

39. Olian J.D., Rynes S.L., Organisational staffing: integrating practice with strategy, "Industrial relations" 1984, vol. 23, no. 2, pp. 170-183.

40. Paladino A., Investigating the drivers of innovation and new product success: A comparison of strategic orientations, "Journal of Product Innovation Management" 2007, 24, pp. 534-553.

41. Peck S.R., Exploring the link between organisational strategy and the employment relationship: the role of human resources policies, "Journal of Management Studies” 1994, vol. 31, no. 5, pp. 715736.

42. Perdomo-Ortiz J., Gonzalez-Benito J., Galenie J., An analysis of the relationship between Total Quality Management-based Human Resources Management practices and innovation, "The International Journal of Human Resources Management" maj 2009, vol. 20, no. 5, pp. 1191-1218.

43. Petroni A., Career route preferences of design engineers: an empirical research, "European Journal of Innovation Management" 1999, vol. 2, no. 2, pp. 63-70.

44. Porter M.E., Competitive strategy: Techniques for analysing industries and competitors, Free Press, New York, 1980.

45. Raghuram S., Arvey R.D., Business strategy links 
with staffing and training practices, "Human Resource Planning” 1994, vol. 17, no. 3, pp. 55-73.

46. Scarbrough H., Knowledge Management, HRM and the innovation process, "International Journal of Manpower" 2003, 24, 5, pp. 501-516.

47. Schuler R.S., Jackson S.E., Linking competitive strategies with human resource management practices, "Academy of Management Executive" 1987, vol. 1, no. 3, pp. 207-219.

48. Sheppeck M.A., Militello J., Strategic configurations and organizational performance, "Human Resource Management” 2000, vol. 39, no. 1, pp. 5-16.

49. Sonnenfield J.A., Peiperl M.A., Staffing policy as a strategic response: a typology of career systems, "International Journal of Human Resources Management" 1988, vol. 13, no. 4, pp. 588-600.

50. Storey J., Quintas P., Fowle W., Flexible employment contracts and their implications for product and process innovation, "International Journal of Human Resource Management” 2002, vol. 13, no. 1, pp. 1-18.

51. Stroh L.K., Reilly A.H., Making or buying employees: the relationship between human resource policy, business strategy and corporate restructuring, "Journal of Applied Business Research" 1994, vol. 10, pp. 12-18.

52. Treven S., Mulej M., A requisitely holistic view of Human Resources Management in innovative enterprises, "Cybernetics and Systems: An International Journal", 2005, 36, pp. 45-63.

53. Versma U., Incremental innovation and HR practices: Some evidence from a Dutch truck producer, "Management Research News" 2000, 23, 9-11, p. 151.

54. Vrakking W.J., The innovative organisation, "Long Range Planning” 1990, vol. 23, no. 2, pp. 94-102

55. Wiklund J., Shepherd D., Knowledge-based resources, entrepreneurial orientation, and the performance of small- and medium-sized businesses, "Strategic Management Journal" 2003, 24(13), pp. 1307-1314. 